\title{
走査型電子顕微鏡における 磁場シールド制振による像ノイズの低減*
}

\author{
羽持 満** 所 裕一郎*** 青島 慎 $^{\dagger}$ 涌井伸二十†
}

Image Noise Reduction Using Magnetic Shield Damping for Scanning Electron Microscope

Mitsuru HAMOCHI, Yuichiro TOKORO, Makoto AOSHIMA and Shinji WAKUI

This paper addresses Scanning Electron Microscope (SEM). Not only the mechanical vibration but also electro-magnetic field influences the quality of SEM image. The vibration of the electron beam path also causes SEM image noise. We investigated the eigen mode shapes of the magnetic shield experimentally, and found out the frequency of the image noise measured with "Spot-beam analysis" corresponded to those natural frequencies. With changing the acceleration voltage of the electron beam, it was shown that the vibration of the magnetic shield affected magnetically to the electron beam path. As countermeasures, the damping structures with and without binding part were applied. Both structures were effective, however the structure with binding part changed the eigen modes of the magnetic shield and the frequency properties of SEM image noise. Thus, the damping structure without binding part would be more desirable to reduce the magnetic shield vibration. The damping structure had been applied to SEM, and remarkable reductions of the image noise from 250 to $500 \mathrm{~Hz}$ band in $1 / 3$ octave band were shown. This effect would be more remarkable when the acceleration voltage of the electron beam was smaller to reduce the electron damage to the specimen.

Key words: scanning electron microscope, magnetic shield, mode shape, natural frequency, acoustic noise

\section{1. 緒言}

走査型電子顕微鏡(Scanning Electron Microscope :以下 SEM と 略記)は, 近年のナノテクノロジーの隆盛にともない必須のツー ルとなった. 半導体の微細化にともない必要な観察倍率はより 高くなり, 最新の SEM は 100 万倍での観察・分析を行うこと ができる.このような高倍率では, 設置環境の騒音や床振動の 伝達によって発生する装置の微小な弾性変形が電子ビーム照射 位置と試料との相対変位をもたらし，これが分解能を超えると 像ノイズとして観察され問題となる. そこで, 装置構造の固有 モードシェイピングによる振動伝達の抑制 1)，また広帯域の動 吸振器による複数固有振動モードの同時抑制 ${ }^{2}$ などの機械的な 対策や，電子ビーム軌道の偏向によって上述の相対変位を補償 する電気的な対策手段 ${ }^{3)}$ を提案した. 一方, 電子ビームは電場 や磁場の変動によっても偏向させられる.つまり, 設置環境の 電場・磁場変動も像ノイズの原因となる. 電場変動の抑制のた めには，同ビームの周囲が金属でシールドされていれば十分で あり特別な対策は必要でない. 一方, 磁場変動の影響を抑制す るためには，一般に透磁率の高いパーマロイ製のシールドが設 けられる. 同素材はコストの観点から装置全体ではなく電子ビ 一ム近傍の必要最小限の部位に用いられる. ヘルムホルツコイ ル式の磁場キャンセラもよく知られているが，装置全体の空間 を十分に補償するのは困難で, 通常磁場シールドと併用される.

本稿では，磁場シールドの振動にともなう副次的な影響に注 目する. シールドの固有振動が周囲の騒音により励起され，こ

*原稿受付 平成 20 年 3 月 21 日

**正会 員 日本電子（株）（東京都昭島市武藏野 3-1-2）

*** 日本電子（株）（東京都昭島市武蔵野 3-1-2）

${ }^{\dagger}$ 日本電子（株）（東京都昭島市武蔵野 3-1-2）

${ }^{\dagger}$ 正 会 員 東京農工大学大学院（東京都小金井市中町 2-24-16)
の強磁性体の振動によって発生する磁場変動が電子ビーム軌道 を偏向する. この複合的な作用が像ノイズの一因となることを 実験的に明らかにした. そして，対策として拘束・非拘束型の 制振構造をシールドに適用し, 像ノイズ抑制の効果を検証した.

\section{2. 走查型電子顕徽鏡亡磁場変動による像ノイズ発生}

\section{1 走查型電子顕微鏡}

SEM の主な構造を図 1 に示す. まず, 電子ビームは電子銃で 発生させられ，コンデンサレンズ，対物レンズで収束された同 ビームを試料の一点に照射する. 走査コイルによってビーム照

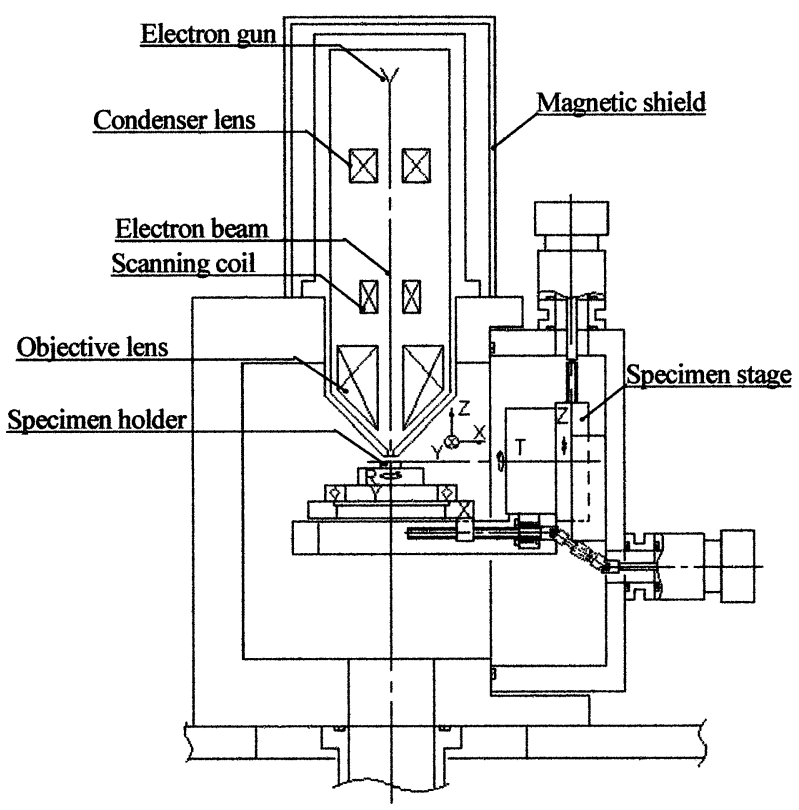

Fig.1 Main structure of SEM 
射位置を試料表面上で 2 次元走查し，そのとき発生する 2 次電 子強度を測定することによって, SEM 像が得られる. 試料を位 置決めする試料ステージは, 図中 $\mathrm{X}, \mathrm{Y}, \mathrm{Z}$ で示す 3 つの直動 と図中 T, R で示す 2 つの回転動とで 5 自由度の位置決めが可 能である. R 動の上に試料を載せた試料ホルダが保持される. 電子ビーム鏡筒の周囲には円筒状の磁場シールドが配置され, 外部の磁場変動の電子ビーム軌道への影響を抑制する.

\section{2 磁場変動による像ノイズ発生}

磁場シールドは設置環境に存在する磁場変動の影響を抑制 するためのものである. しかしながら，シールドは厚さ $2 \mathrm{~mm}$ のパーマロイ板であり比較的軽量で面積が大きいため, 周囲の 騒音によって容易にその固有振動モードが励起される.このと き, 強磁性体であるシールドの振動によって磁場変動が発生す る. つまり, 騒音が磁場変動の原因となる. この磁場が電子ビ 一ム軌道を偏向させれば試料への照射位置が変動し SEM 像ノ イズが発生する. 近年, 試料への電子ビーム照射によるダメー ジを軽減させるため, 低加速電圧の電子ビームによる観察が行 われることが多い. 電子ビームが一定距離を進む間に，ローレ ンツカによってその直交方向に偏向される量, すなわち像ノイ ズ振幅は加速電圧が低いほどより大きくなる. 電圧 $V \mathrm{~V}]$ で加速 された質量 $m[\mathrm{~kg}]$, 電荷 $e[\mathrm{C}]$ 電子が, 一定距離 $L[\mathrm{~m}]$ だけ進ん だときにその直角方向への偏向量 $\delta[\mathrm{m}]$ は式(1)で示される. な お, $B[\mathrm{~Wb}]$ は電子の進行と直角方向の磁束密度である.

$$
\delta=\frac{1}{4} B L^{2} \cdot \sqrt{\frac{2 e}{m V}}
$$

ここで, $B, L, e, m$ は一定であるので, 電子ビームの偏向量 $\delta$ は, 加速電圧 $V$ の $1 / 2$ 乗に反比例する.

\section{3. 磁場シールド振動の影響調査と対策}

\section{1 磁場シールド振動の影響調査}

\section{1 .1 像ノイズの周波数解析}

SEM 像ノイズの周波数成分を特定する方法の一つとして, ス ポットビーム解析がある. これを図 2 で説明する. SEM 像を取 得する際は左上のように, 破線で示す電子ビームで試料表面を 2 次元走査する. このとき試料あるいは電子ビームが振動する と，左下に示すように像ノイズが観察される. 右上のように実 線で示す電子ビームを走査せずに明暗のコントラストが大きい 試料のエッジに照射すると，右下のようにビームと試料との相 対振動にともない試料から発生する 2 次電子の強度が変動する. スポットビーム解析は, この 2 次電子信号強度の時間変化を測 定しFFT アナライザで周波数解析するものである. この方法で 得られるスペクトルは相対変位，すなわち像ノイズ振幅を反映 している. よって, 各ピークの高さを比較することでそれぞれ の周波数成分の影響を比較できる.

SEM の正面よりピンクノイズ信号による音響加振を行い, ス ポットビーム解析を行った. 等価音圧レベルは $90 \mathrm{~dB}$ (平坦特性) とした. 図 1 の試料ステージにおいては, Z 動を利用して試料 ホルダを対物レンズ下部に接触させ, 試料の機械振動を抑制で きる. 試料ホルダを接触させる前後で測定した結果をそれぞれ 図 3 の上下に示す．縦軸は相対值である. 試料ホルダを対物レ ンズへ接触させたときにも $282,319,488 \mathrm{~Hz}$ の成分は観察され, 他のピークは相対的に抑制されていた. よって, これらの像ノ イズ成分は試料の機械振動によるものではないと判明した。つ まり, 像ノイズ量は装置の弾性変形による電子ビーム照射位置
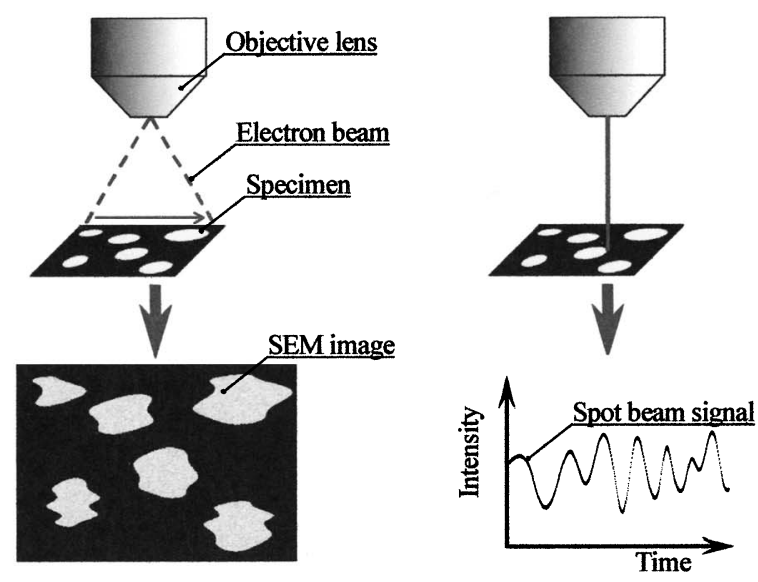

Fig.2 Spot beam analysis

と試料との相対変位量と同ビームの電場や磁場変動による偏向 量とを足し合わせたものである. また本装置において, 電子ビ 一ムの偏向による影響は, 騒音による像ノイズ成分として支配 的であることがわかった.

\section{1 .2 磁場シールドの固有振動調查}

試料ホルダの固定に影響されない像ノイズ成分は, 電子ビー ム軌道の偏向によるものである. そこで, 磁場シールドの固有 振動との関連を調查した．接触子の先端を球面にした加振機 (MORITEX 社, MA25/6 型)をシールドの外周面に垂直に接触さ せ, 像ノイズ周波数に一致させた正弦波加振を行った. このと き観察された像ノイズは, 非磁性材の接触子をわずかに離すと 消失し, 加振機の漏孔磁場の影響ではないことを確認した. 接 触子で表面上をトレースすると像ノイズが見られなくなる点が 確認された. これらはシールドの固有モードにおける振動の節 である.逆に,像ノイズ振幅が最大となる点は振動の腹である.

これを利用しモードシェイプを調查した. $282 \mathrm{~Hz}$ で正弦波加振 したときの結果を図 4 に示す．節と腹に相当する点にそれぞれ
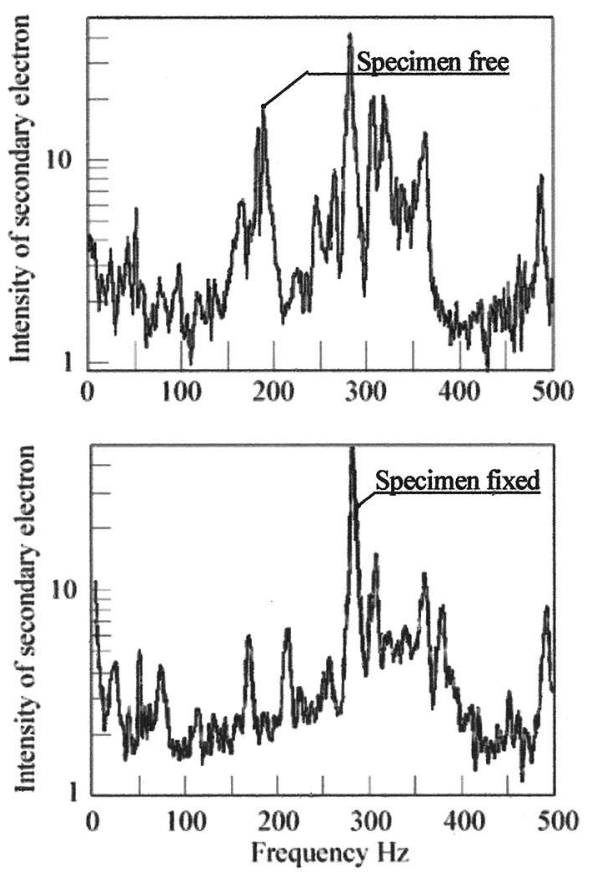

Fig.3 Image noise spectra under random acoustic noise exposure 


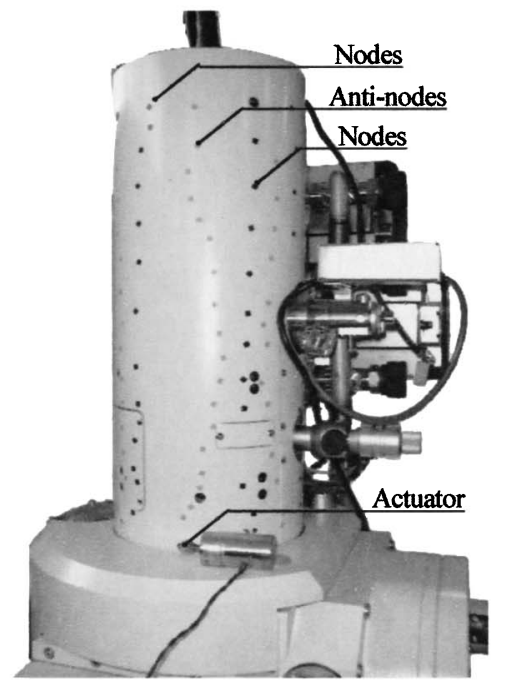

Fig.4 Mode shape measurement of magnetic shield at $282 \mathrm{~Hz}$

シールを貼り付けた. なお, シールド表面にいくつか見える黒 い丸はメンテナンス用の穴である. 振動の節と腹とはそれぞれ 綐方向の線状に，シールドの円周方向に交互に現れた. この振 動モードは，円筒の固有モード 4)である．軸対称な円筒の固有 モードは数值モデルでは，節あるいは腹が等間隔に並ぶが，本 装置のシールド形状は非対称でかつ複数部品より構成され, 数 ヶ所においてボルトで固定されているため, 対称なモードシェ イプを示さない．通常の実験モーダル解析では測定点を非常に 多くしない限り，このような複雑な振動シェイプを捉えること は難しく，本実験の方法は有益なものである. $319 \mathrm{~Hz}$ でも同様 の調査を行い,やはり腹と節とが交互に現れることを確認した. また, これらの周波数の前後に加振周波数を変化させるとそれ にともなって SEM の像ノイズ量は减少し，これらの周波数で 極大值を示すことも確認した. 以上から, 磁場シールドの固有 振動が像ノイズの原因になっていることが明らかになった。 し かし，これだけではシールドの振動による磁場変動が影響して いるのか，あるいは機械振動が伝達して影響しているのかは判 断できない，そこで，電子ビームの加速電圧を変化させたとき に像ノイズ量が変化するかどうかを確かめた．上記加振機を磁 場シールドの一ヶ所に固定し $282 \mathrm{~Hz}$ で正弦波加振したときの SEM 像を, 加速電圧がそれぞれ $15,5 \mathrm{kV}$ の場合で比較した. 結果を図 5 に示す．低加速電圧のときに像ノイズ振幅の増加が 認められた. 図中の矢印で示す像ノイズ振幅 を比べると, 加速 電圧 $5 \mathrm{kV}$ の像ノイズ量は $15 \mathrm{kV}$ のときの約 1.7 倍であり, 式(1) から導かれる電子ビーム偏向量の比である $\sqrt{ }(15 / 5)=\sqrt{ } 3 \fallingdotseq 1.73$ に一致した. したがって, 磁場シールドの振動は機械的な振動 としてではなく磁場変動として電子ビーム軌道に影響し像ノイ ズ原因となっていることが明らかとなった.

\section{1 .3 騒音による磁場シールド固有振動の励起}

設置環境の騒音によって磁場シールドの振動が励起されるこ とを確かめるため, 図 6 に示すように, 試料チャンバに静電容 量型非接触変位計を固定し，磁場シールドとの相対振動を測定 した. 測定位置は装置正面側である.ピンクノイズの音響加振 を行ったときの相対振動を測定し，周波数分析した結果を図 7 に示す．本測定は調査の都合により，振動モードシェイプの測 定に用いたものとは別の装置において行われた，そのため周波 数には機差が存在する. 図 3 下段に観察された像ノイズピーク:

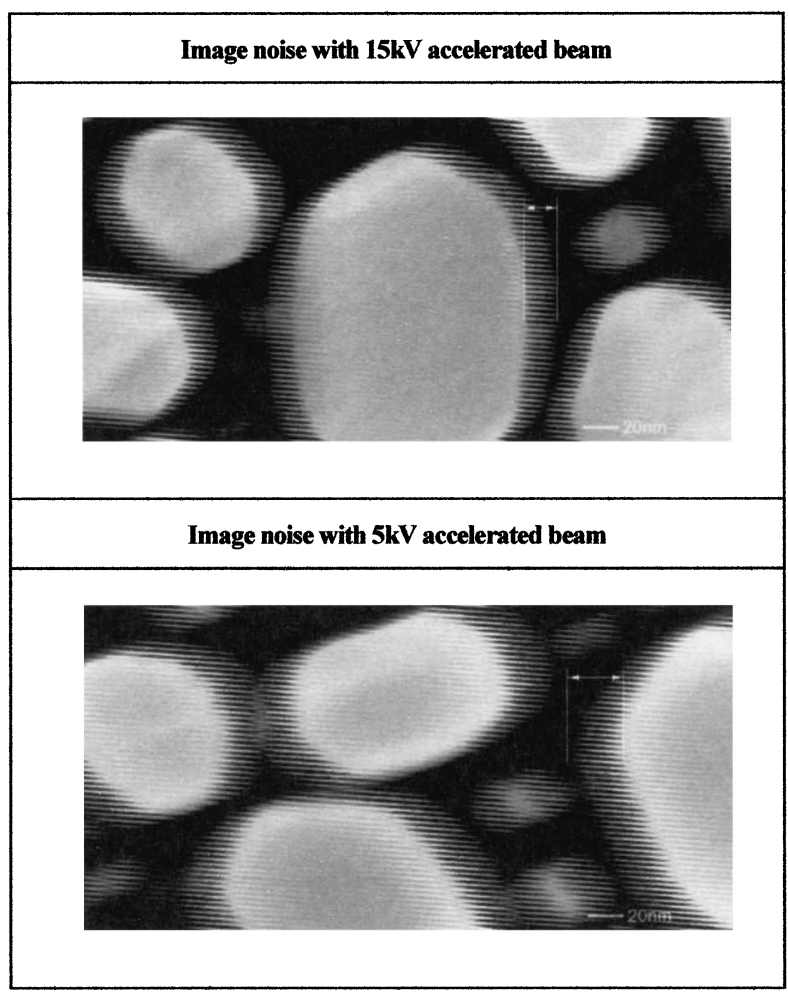

Fig.5 Difference of the image noises with the variance of acceleration voltage of the electron beam

$282,319,488 \mathrm{~Hz}$ に近接した $260,323,498 \mathrm{~Hz}$ に振動のピーク が観察された．なお，振動スペクトルの測定はシールドの一カ 所において測定されたものであり，各ピークの大きさと像ノイ ズ量, すなわち磁場変動量との直接的な関連性は議論できない.

3.2 磁場シールドの制振による対策

薄板構造の制振には，拘束型あるいは非拘束型の制振構造を

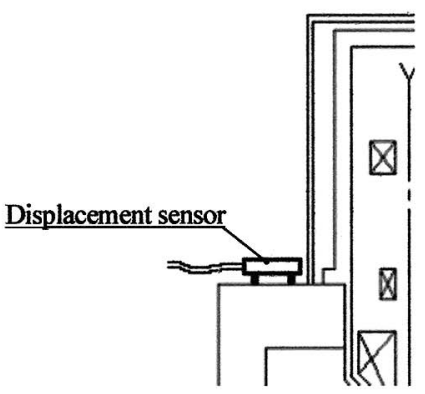

Fig.6 Vibration measurement of magnetic shield

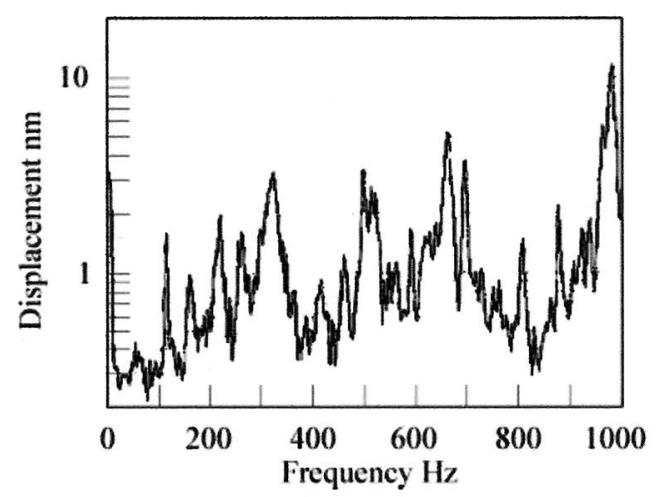

Fig.7 Displacement spectrum of magnetic shield under random acoustic noise exposure 


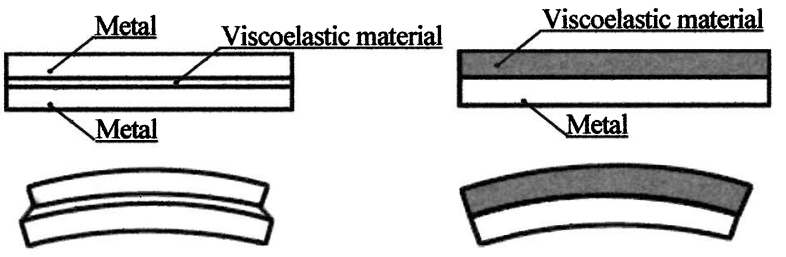

Fig.8 Damping structure with and without binding part ${ }^{5}$ )

用いる方法が知られている ${ }^{5}$. 図 8 に両者の構造を示す. 拘束 型の制振構造は，図中左上のように制振する対象と同等の剛性 を持つ部材により減衰能の高い粘弾性材を挟み込む 3 層の構造 をなし，左下のように中間部材のせん断変形による減衰により 制振を行うものである. それに対し，非拘束型の制振構造では 右上のように相対する部材を用いず，右下のように粘弾性材の 伸縮変形により制振作用をもたらす．まず，薄い粘弾性層のせ ん断減衰を利用する拘束型の制振構造の方が微小振動の制振に 有利と考え，その効果を検証した. これは厚さ $0.3 \mathrm{~mm}$ のアルミ 板の表面に $50 \mu \mathrm{m}$ の粘弾性材の薄膜が設けられたものである. これをシールド内側面のほぼ全面に貼り付けた. 拘束型制振構 造の取り付けを行う前後で, 1/3 オクターブバンドパスフィル タを通したランダムノイズの音響加振下で SEM 像を比較した. 周波数域は, 磁場シールドの固有振動数を含む 200 から $500 \mathrm{~Hz}$ 帯とした. 結果として，像ノイズの減少は $250,315 \mathrm{~Hz}$ 帯で認 められた. 図 9 に, 最も高い効果の見られた $315 \mathrm{~Hz}$ 帯の音響加 振下における SEM 像の比較を示す. しかし，その一方図示し ないが $400 \mathrm{~Hz}$ 帯においては若干の像ノイズ増加が観察された. 図 10 に, 拘束型制振材の適用前後におけるピンクノイズ音響加 振下のスポットビーム解析結果を示す．両グラフ間でピーク高 さの絶対值を比較することはできない. それぞれのグラフ内に

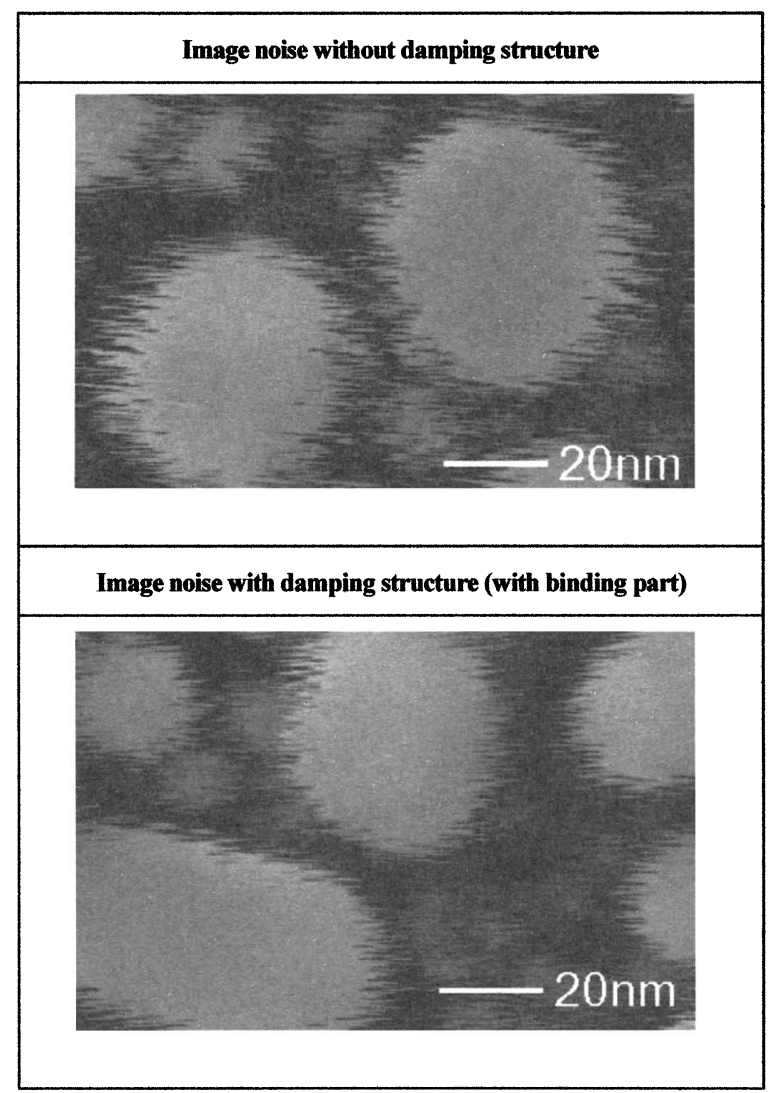

Fig.9 SEM images under $1 / 3$ octave band acoustic noise $(315 \mathrm{~Hz})$
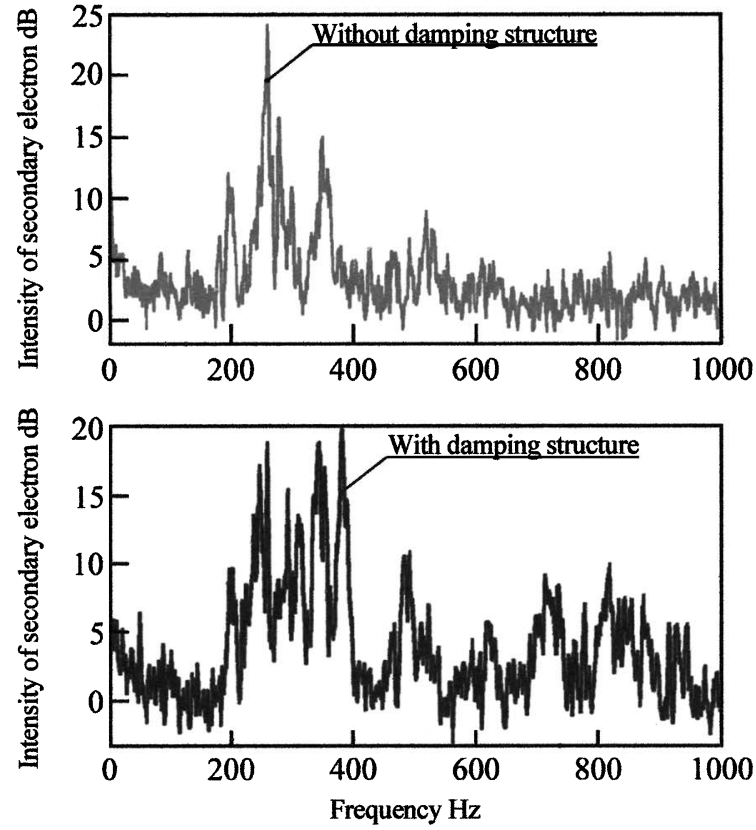

Fig.10 Image noise spectra under random acoustic noise exposure with and without damping structure

おいて,像ノイズの各周波数成分の相対比較のみが可能である. 拘束型制振材の適用前において相対的に大きかった $260 \mathrm{~Hz}$ の成 分が, 適用後には抑制され,一方 $380 \mathrm{~Hz}$ の成分は増加している. 拘束型の制振構造は, 制振対象に減衰能だけではなく剛性と質 量とを付与するため, 磁場シールドの固有振動数を変化させる. つまり，装置の音響に対する周波数特性に影響を与える. 像ノ イズ量は, 振動や磁場変動など, それぞれに周波数特性を持つ 要因の総和である. 例えば, 試料ステージの固有振動数と磁場 シールドの固有振動数とが制振材の適用によって近接した場合 には, 両者による影響が加算されてこの周波数帯の騒音に起因 する像ノイズ量はかえって大きくなる可能性がある. 逆にこれ らの周波数帯がもともと近接している場合には，一方の固有振 動数を変化させることでその周波数帯の像ノイズ量を抑制する ことができる. しかし，それぞれに複数の固有モードを持つ多 数の構成要素の固有振動数に関して, すべてが近接しないよう に設計することは容易でない. よって, 悪影響の起こるリスク を避ける観点から, それぞれの固有振動数に影響を与えず减衰 能のみを付与できるほうが望ましい. そこで次に，拘束型に比 べ質量と剛性の付与が少なく, したがって磁場シールドの固有 振動数の変化がより少ないと期待される非拘束型の制振機構を 評価した. 本稿で評価した非拘束型制振材は塗料でありこれを 磁場シールドの内側面に厚さ約 $0.6 \mathrm{~mm}$ で塗布した. 今回は装置 実装に先立ち, 制振材塗布前後でインパルス応答の変化を測定 した. 図11のように,ビニール製の紐で磁場シールドを吊るし， 上部をハンマでシールドの長さ方向にインパルス加振したとき, その下部に円筒の径方向に取り付けた加速度計を用いて加速度 の時間波形を測定した. これらの信号には複数の周波数成分が 含まれているため, 減衰する波形を FFT 解析し指数平均値をも って各周波数成分を比較した. 減衰能が大きいほどスペクトル のピークはより低くなる. 結果を図 12 に示す. 図に見られるピ 一ク周波数はシールド単体のものであり実装状態とは異なるが, 各ピーク周波数は制振材塗布前後でほとんど変化していない. よって, 実装状態においてもシールドの固有振動数は変化しな 


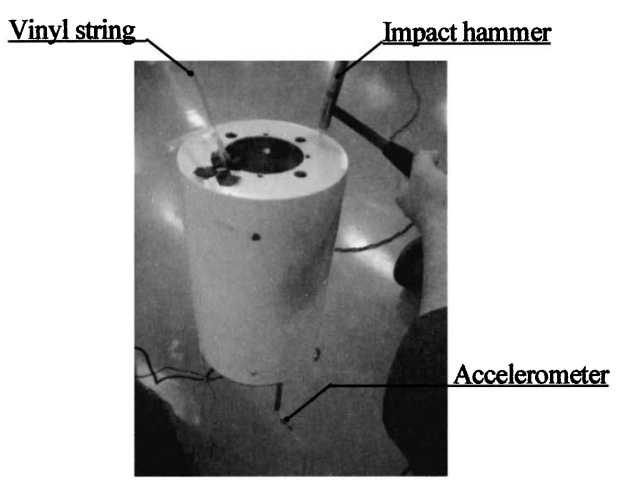

Fig.11 Transient hammer response measurement

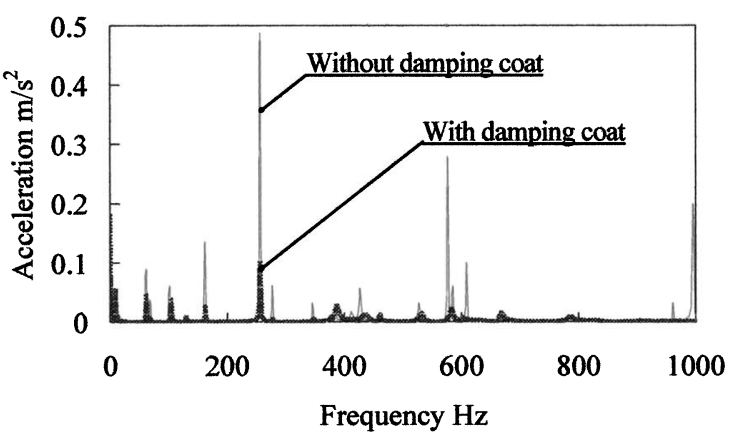

Fig.12 Spectra of the transient signals of the hanged magnetic shield

いと推定される. また $60 \mathrm{~Hz}$ 付近に見られる低周波数のピーク から制振効果が認められた. 次に, この磁場シールドを制振処 理していないものと交換する前後において，音響加振下での $\mathrm{SEM}$ 像を比較した. ビームの加速電圧は $15 \mathrm{kV}$ である. 音響加 振の周波数範囲は $63 \mathrm{~Hz}$ から $2 \mathrm{kHz}$ 帯までとした. 結果として, 250 から $500 \mathrm{~Hz}$ 帯において，像ノイズの減少が認められた．ま た, 拘束型の制振構造のときと異なり, 像ノイズが増加する周 波数帯は観察されなかった. 効果が最も顕著であった $400 \mathrm{~Hz}$ 帯 のSEM 像の比較を図 13 に示す. 像ノイズが増加する周波数帯 がなかったことは, 図 12 において非拘束型制振材が磁場シール ドの固有振動数に影響しなかったことに対応している. 今回評 価した非拘束型制振材の効果は図 13 に示したように実用上十 分に高いものであった. また，前述の拘束型制振構造を適用し た場合よりも高い効果を示していた. 拘束型制振構造をマイナ ス曲率の円筒面内側に密着させることは容易でない. 一方, 今 回採用した非拘束型制振材は，厚さを十分にするため塗布・乾燥 工程を繰り返す必要があるが, 高い密着性を容易に得られるた めに，より優れた制振効果が得られたと思われる.さらに，既 述のように拘束型の制振材は磁場シールドの固有振動数に影響 を与えるため, 今回の用途には非拘束型のほうが適している.

本稿の制振処理を施した磁場シールドは，既に製品に適用さ れている. 近年は, より試料ダメージの少ない $0.5 \mathrm{kV}$ 程度の低 加速電圧で像観察が行われることも多い. この場合, 磁場によ る電子ビーム偏向量は加速電圧が $15 \mathrm{kV}$ の場合の約 5.5 倍になる. したがって，磁場シールドの制振が騒音による像ノイズを抑制 する効果はより顕著となる.

\section{4. 結 言}

SEM の像ノイズ原因は機械的な振動のみではない，電場・

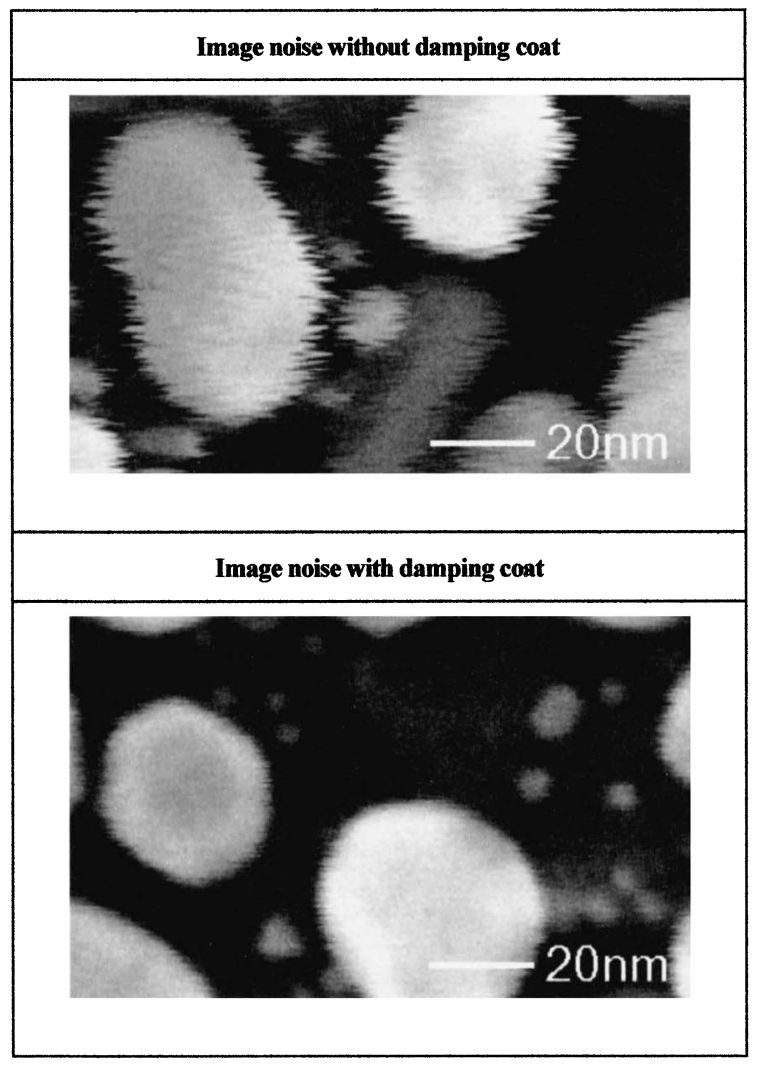

Fig.13 SEM images under $1 / 3$ octave band acoustic noise $(400 \mathrm{~Hz})$

磁場の変動は電子ビームを偏向し像ノイズをもたらす.本稿は, 騒音外乱が磁場変動に変換され像ノイズの原因となるという, 複合的な影響に関する初めての報告である.

(1) まず装置のランダム音響加振下におけるスポットビーム 解析によって, 試料の対物レンズへの接触固定による機械 的相対振動の抑制に影響されない像ノイズ周波数成分を 特定した. 次に磁場シールドの振動測定により，それらの 周波数が音響加振で励起されたシールドの固有振動数と 一致していることを確かめた．また，シールド表面に対す る正弦波加振の走查と像ノイズ振幅の増減との関係から, これらの周波数におけるシールドの固有モードシェイプ を明らかにした. 最後に, 電子ビームの加速電圧を変化さ せることにより, シールドの振動が機械振動としてではな く磁場変動として像ノイズの原因となっていることを示 した.

（2）拘束・非拘束型の制振構造をシールドに適用し，それぞれ において像ノイズの低减を確かめた。拘束型の制振構造は 減衰能の付与だけではなくシールドの固有振動数に影響 を及ぼす.一方，非拘束型では固有振動数への影響が見ら れず，减衰能の付与のみを行うことができた.

\section{考 文 献}

1) 羽持満, 涌井伸二 : 走查型電子顕微鏡における振動モードシェイピ ングによる像ノイズの低减, 精密工学会誌, 73，6(2007)665.

2) 羽持満, 青島慎, 涌井伸二: 広帯域動吸振器を使った走査型電子顕 微鏡の騒音像ノイズの低减, 精密工学会誌, 74, 2(2008)188.

3）羽持満，大橋茂，須賀三雄，涌井伸二：走査型電子顕微鏡における 電子ビーム偏向による像ノイズの低減, 精密工学会誌, 73, 9(2007)1080.

4) 谷口修: 振動工学ハンドブック, 養賢堂(1981)109.

5) (社)日本機械学会編 : 振動のダンピング技術, 養賢堂(1998)126. 